\title{
Analysis on the Necessity of Military Training in the Cultivation of Patriotism of College Students
}

\author{
Wansong $\mathrm{Hu}$ \\ Zhongnan University of Economics and Law, Wuhan, Hubei, 430073, China
}

Keywords: Military training; College students; Patriotism; Necessity

\begin{abstract}
The spiritual character of patriotism can be greatly strengthened and embodied in military training. Cultivating the quality of patriotism of contemporary college students is conducive to inspiring their patriotism and helping them to establish a correct political outlook and values. In view of this, this article takes contemporary college students as the research object, focusing on the necessity of training military activities in the cultivation of contemporary college students' patriotism. Finally, it makes further consideration on how to cultivate contemporary college students' patriotism in military training activities. I hope the discussion in this article can be of some reference to the study of Chinese college students' patriotism education.
\end{abstract}

\section{Introduction}

Patriotism is an excellent tradition of the Chinese nation, an important force in promoting the current economic and social development in our country, and an important part of the socialist spiritual civilization. At the Central Political Bureau's collective meeting, General Secretary Xi Jinping pointed out that patriotism education should be run through to education for all so that the patriotic education can be firmly rooted in the hearts of young people. The college student stage is an important period for students to establish a correct world outlook, outlook on life and values. It is also an important preparatory stage for them to enter society. To educate and guide the university students' patriotism, cultivate their patriotism and raise their awareness of patriotism is of great practical significance for the growth of college students and the development of the Chinese nation. Military training, as the most basic form of military service for university students, contains many patriotic educational resources. The full implementation and implementation of military training for college students is an important measure to cultivate the patriotism character of contemporary college students.

\section{The Contents of Military Training in Universities}

At the beginning of the last century, the relevant departments of the Ministry of Education and the General Political Department of China had jointly issued the "Notice on Proposals for Held Military Training Activities in Universities and High Schools." In the notice, the need for college students to participate in military training was clearly stated, and military training for college students was required to be incorporated into the educational task system. At the same time, the notice also clearly put forward the specific matters of military training for college students from the theoretical study and skills training in two aspects. The main contents of military training in contemporary universities are implemented according to the revision of "general plan for military training of general university students" in 2002. The specific content of the planned military training for college students is shown in Figure 1: 


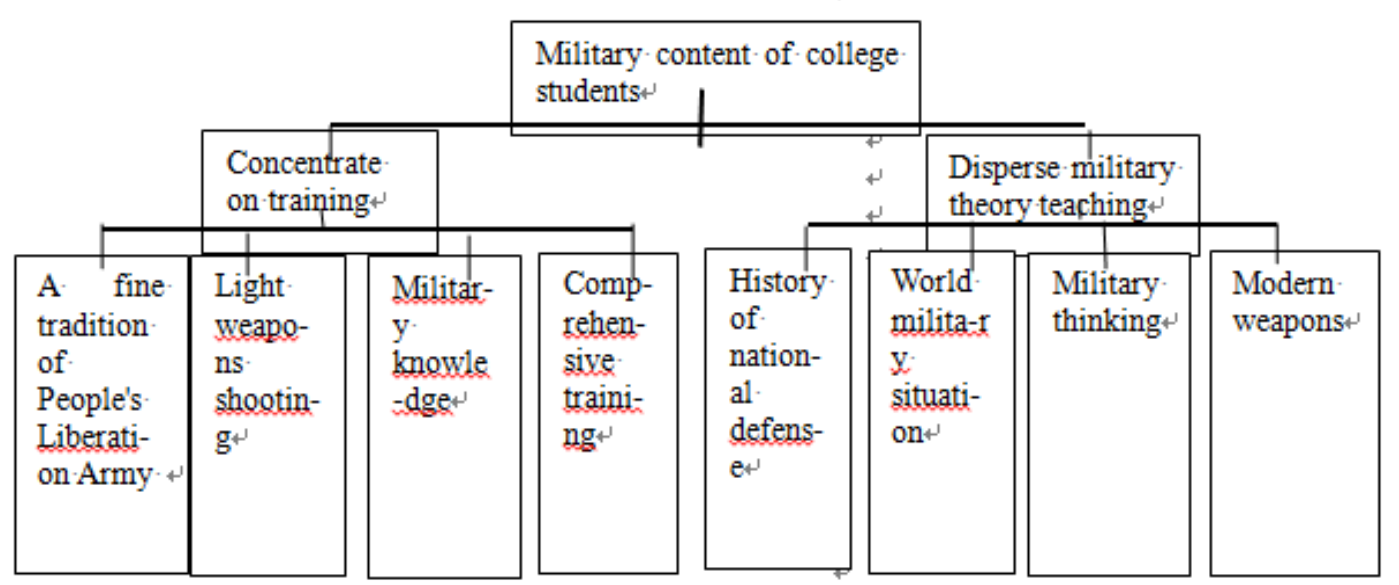

Figure 1. University military training content

From Figure 1, we can see that the content of contemporary college students' military training includes two parts: intensive training and decentralized teaching of military theory. Concentrated training contains the PLA's fine traditions, light weapons shooting, military knowledge and comprehensive training four subjects. The four subjects covered in the teaching of decentralized military theory include history of national defense, world military situation, military thinking, and modern weapons. Concentrating on training is the highlight of military training in universities and the foundation for mastery of basic military theories and skills. Decentralizing the teaching of military theoretical courses is an important part of deepening military training for college students and an indispensable educational process for comprehensively improving the quality of political and military education for those participating in military training.

\section{Analysis on the Necessity of Military Training in the Cultivation of Patriotism of College Students}

The Chinese nation is an ancient nation that has experienced thousands of years of development and change. As the times change, great changes have taken place in politics, economy and culture in our country continuously, which make people gradually become estranged from the concept of home and country. After the reform and opening up, due to the gradual establishment of new concepts of development and ethics, this has to some extent promoted the social and economic development of our country. However, in this process, some decadent thinking in the market economy seriously erodes people's values. Monetaryism and individualism have gradually diminished the concept of family and national feelings, as a result, the desires of some people have been swelled and their moral concepts have had a serious decline. This has seriously affected the harmony between family and society and the patriotic feelings of "benevolence, filial piety, loyalty and righteousness" have gradually been thrown away.

The people are the creators of history and the main force to realize the great rejuvenation of the Chinese nation. In order to realize the Chinese dream of the great rejuvenation of the Chinese nation and patriotism, we should integrate the traditional home culture of the Chinese nation with the contemporary spirit. Every sons and daughters of China should have a high sense of national identity and spiritual ownership, and a sense of responsibility and mission to realize the rejuvenation of the Chinese nation. Only by establishing the spirit of patriotism in the homeland and by combining the future of the individual with the destiny of the country can we promote the sustainable development of both individuals and our country.

The history of humiliation in China's modern history proves that only by building a mighty military force can it safeguard its homeland. Contemporary college students in times of peace do not need to fight bloody battles on the battlefield, but developing the patriotic character in military training is both necessary and of great importance.

First of all, the cultivation of patriotic character can enable students not only to pay attention to 
their own affairs in the military training, but also to be concerned with the realization of the rejuvenation of the Chinese nation. Students can set up the spirit of patriotism and nationalism in the military training and establish a sense of responsibility so as to consciously shoulder the historical mission entrusted by the times.

Second, the cultivation of patriotic character can enable students to establish the spirit of corporatism and train their team spirit in military training activities.

Thirdly, the cultivation of patriotism is good for the contemporary college students to learn the outstanding qualities of the military and the revolutionary heroism, so as to cultivate their strong will and the quality of hard work.

\section{Further Reflection on the Cultivation of Patriotism Character in College Students' Military Training}

First, contemporary college students not only need to receive military training, but also must actively devote themselves to military training ideologically, so as to establish a correct military training concept. Military training is to cultivate college students awareness of national sovereignty and national interests, is the main way to achieve patriotism education. However, at present, due to some obvious defects in the understanding of military training among some college students, a theory of useless military doctrine has emerged. In view of this phenomenon, it is very important that we strengthen the ideological guidance of university students in military training so as to help them establish a correct "military training concept."

Second, the contemporary college students should put the knowledge of the army theory into practice based on the establishment of a correct ideological understanding, reinforce the military theoretical knowledge in practice, strengthen the ideological and political education, and cultivate the feelings of patriotism. Through routine military practice training activities, students can not only improve their self-help ability in the face of a disaster but also arouse their enthusiasm in military training, so as to establish their determination to protect their country and enhance the effect of military training in college students' patriotism education.

\section{Conclusion}

The patriotism of "family-in-one" can be well reflected in college students' military training activities. In the military training activities, the cultivation of the quality of patriotism is the main way to cultivate the spirit of patriotism of college students, inspire the patriotism of college students, establish the correct values and outlook on life of college students, and strengthen the sense of responsibility and national mission of college students. Under the background of constructing the Chinese dream, only by establishing the patriotic feelings of contemporary college students and linking their personal future with the destiny of the country can their real value be realized.

\section{Reference}

[1] Yun A P, Yang D H. On the Combination of Modern National Defense Consciousness and Patriotism Education among College Students in Military Lesson Teaching[J]. Technology Innovation Guide, 2012,19:169.

[2] Zhang C L. On the Significance of Military Training in Quality Education of College Students[J]. Journal of Changchun University of Science and Technology, 2010,03:133-136.

[3] Cai H M. Give Full Play to Military Training in College Students' Quality Edu cation[J]. Journal of Zhongnan Forestry College, 2004,03:61-64. 